\title{
Educating Children and Youth in Care in Alberta: A Scoping Review
}

\author{
Munyaradzi Hwami \\ University of Alberta \\ hwami@ualberta.ca
}

\begin{abstract}
Alberta Education and Alberta Children Services have reported consistent low achievement in school by children and youth in care, especially those in residential group care. This article provides the current picture of research and practice regarding the education experience of children and youth in care. Utilizing a scoping review of local and international research studies, the paper argues that the education of children in care in Alberta is not considered an important issue. The dominance of the social work paradigm in children and family services is exposed as inadequate, and hence the call for social pedagogy to be adopted. Determinants of educational achievement for children and youth in care are examined and using these attainment factors, the article identifies and recommends areas that Alberta Education and Alberta Children Services need to consider with urgency if children and youth in care are to benefit from schooling like all other children.
\end{abstract}

\section{Introduction}

Education is recognized as an investment in children's futures. Education is also compulsory in Alberta, Canada, and parents and guardians have an obligation as outlined in the School Act (2000) to ensure that their children attend school. Statistics from Alberta Education, nationally and internationally show that children and youth in care are one of the most educationally vulnerable groups (Dill, Flynn, Hollingshead, \& Fernandes, 2012). The achievement gap between children and young people in care, when compared to children living with their biological parent, is astronomically high. While many groups of students in Alberta, for example, by consideration of their gender, indigenous background, socioeconomic and regional concerns, student and school-based factors (Gunn, Chorney, \& Poulson, 2008), have received attention and consequently intervention policies to enhance their educational experiences, children and youth in care are still to get this deserved attention. Intervention children and youth, also referred to as children and young people in care, residential children or looked after children and youth have the lowest attendance, achievement, and completion rates than their peers (Alberta Education, 2009). The term intervention children and youth is invariably referred in literature and here to mean the same as all the following: children and young people in care or foster children or foster care or looked after or looked-after or out of home care or out-of-home care or out of home placement or out-of-home placement or residential care or state care or public care or kinship care or in care.

The impact of poor school performance transcends academic achievement (Gilligan, 2007). Without graduating from high school, let alone progressing to postsecondary education, youth transitioning out of care are often destined to experience unemployment - or when jobs are secured, they are lower paying (Cheung \& Heath, 1994; Reid, 2007). Academic success is Journal of Contemporary Issues in Education, 2018, 13(1), pp. 3-22 
critical to ultimately achieve positive results regarding social development and economic wellbeing (Representative for Children \& Youth \& the British Columbia Office of the Provincial Health Officer, 2009; Tweedle, 2007). International research identifies a lack of education, unemployment, low earnings, early child rearing, justice system involvement, health issues, social services dependency, stable housing to be among familiar characteristics of youth who have exited care throughout the world (Tweedle, 2007), and this is no different in the context of Ontario (Snow, 2009; Ghabaraghi, 2011).

In Alberta, child and youth services provide care to children and youth under the age of 18 years who are under the guardianship of a director designated under the Child, Youth, and Family Enhancement Act (2000). A range of programs including group homes, foster care, kinship care, secure services, youth emergency shelters and youth assessment centers are classified as child and youth programs and are licensed under the Child, Youth and Family Enhancement Act. Most of these programs are operated by not-for-profit or profit organizations, and some by the government. Some of the major agencies in Edmonton/Alberta include the Catholic Social Services, Unlimited Potential Services, McMan Youth, Family and Community Services among many others. According to the Child Intervention Division, at the end of March 2017, 7174 children were in care in Alberta $(2017$, p. 1$)$ and of this $69 \%$ were of indigenous background.

It is evident that the field of children services is currently driven by Indigenous children and youth. Some critics, have described the current children and youth care as the modern version of residential schools (Humphreys, 2014; Sherlock, 2017) despite the strong supervision provided by modern government with emphasis on children's rights. Today's residential group homes on average can hold up to ten children in one house. It is well established that Indigenous children throughout Canada are behind educationally mainly because schools in Indigenous communities face funding inequalities (Chiefs Assembly on Education, 2012; Morin, 2017; Phillips, 2011). When Indigenous children are admitted into care, they further encounter educational problems because they are dealing with separation issues as well as well as cultural shock. While these observations are critically important and further help explain lower educational outcomes among Indigenous children, they do not shade light on the other children and youth who are not Indigenous, and whose educational performance is not better.

Children and youth in care encountered difficult family and home experiences, and the state had to intervene. Ghabaraghi (2011) observed the following about children and youth in care:

- They are far more likely to be incarcerated than any other group of young people, often repeatedly.

- They run away more often and spend more time on the streets, and this is more common with those in group homes than their counterparts in foster care.

- They are more likely to have diagnosed or undiagnosed mental health concerns.

- They use and abuse substances and alcohol more frequently.

- They are far more likely to be suspended or expelled from school.

- They have the greatest struggles during their transition to independence and therefore are the most likely to either end up homeless or to return to the family following their time in care, even when this is associated with very high risks. (p. 11) 
The education of children and youth in care has been observed as disturbing and not getting required attention (Berridge, 2007; Ghabaraghi, 2011). Children and youth in care are not getting an educational experience as would be expected in a developed country such as Canada. Relative to children residing with their biological families, children and youth in care are not only more likely to score significantly lower on standardized tests (Eckenrode, Laird, \& Doris, 1993; Leiter \& Johnsen, 1997), but they are also more likely to experience grade retention issues, expulsions, suspensions and absenteeism (Stone, 2007; Gabaraghi, 2011). According to Alberta Education (2017), educational achievement results for children and youth in care compared to all Alberta students show:

- Fewer children and youth in care complete high school. Those who do, take longer to do so when compared with other Alberta students.

- The average provincial achievement test results are lower for children and youth in care in all grades and subjects. The gap widens from Grades 3 to 6, and again at grade 9, at both the acceptable and excellence levels.

- More children and youth in care (Grades 1 to 9) need special education support. Despite this disturbing portrayal, there has been very little research that has been done in Alberta on the education of this category of children. Poor performance in school is topical in educational discourses and the absence of continued concern and research on looked after children is a dent in Alberta's education system. Some educational programs, such as the Success in School initiative, Advancing Futures Bursary (Alberta Education, 2017), have been put in place to improve the educational experiences of children in care.

Explanations of the low educational achievement by children and youth in care have concentrated on the children's upbringing. Residential group homes, where intervention children live are where the explanation of their poor school performance can be located (Ghabaraghi, 2012; Berridge, 2012). Others have considered the child's condition as important. The early upbringing of the child together with a healthy and supportive family is vital for intellectual development, and hence the living conditions before intervention become an area of analysis (Ferguson \& Wolkow, 2012; Forsman \& Vinnrljung, 2012). Equally important is the quality of the school and this includes teacher qualifications and motivation, learning resources and an accommodating environment, and research shows that not all schools and educators welcome children and youth living in care homes (Cheung, Lwin, \& Jenkins, 2012; Ghabaraghi \& Grosleg, 2010; Höjer \& Johansson, 2012).

It is from these observations that this article set to examine the state of education of children and youth receiving government intervention services and living in residential group care homes. The paper is a scoping review of research and publications that consider the education of looked after children and youth. The paper aims to:

1) highlight the state of research and existing evidence-based practice in the education of children and youth in care in Alberta.

2) consider and capture some of the major observations and conclusions from national and international researchers into the education of children and youth in care.

3 ) initiate debate and challenge educators and researchers on the need to seriously consider the education of looked after children in Alberta by identifying the absence of educationally

Journal of Contemporary Issues in Education, 2018, 13(1), pp. 3-22 
informed theories in Alberta Children Services practices where social work is currently the dominant paradigm.

\section{Method}

According to Colquhoun et. al., (2014), a scoping review is a form of knowledge synthesis that addresses an explanatory research question aimed at mapping key concepts, types of evidence, and gaps in research related to a defined area or field by "systematically searching, selecting and synthesizing existing knowledge" (p. 67). This study involved an examination of research studies that were relevant to the issue of education of children and youth in care. The central concepts or variables considered were education achievement, children and youth in care, the influence of residential homes (caseworkers and residential workers) and school factors (teachers, school accommodation, etc.). These concepts determined the protocol that was employed, and this provided the criteria to include and exclude individual studies, and to identify relevant data. In line with the research study objectives, the body of literature was analyzed to provide a picture of education provisions that are made available to children and youth in care in the province of Alberta. A consideration of studies done outside Alberta and Canada was intended to enable comparative analysis. This was because of the author's general observation from scanning literature that Alberta Education and Children Services appear to be far behind when it comes to the education of children and youth in residential care homes. As a result, this paper is a form of summarizing and disseminating research findings to policymakers, practitioners, and the general population to inform practice (The Joanna Briggs Institute, 2015) in child and youth care. It involves knowledge mobilization and transfer aimed at developing consciousness on the apparent neglect of the education of children and youth in care. The population of children and youth receiving government intervention services is growing as the modern society fail to find solutions to challenges causing the breakdown of the institution of the family and substance and drug abuse among many other social shocks that are driving today's young people into the city's streets.

I followed Arksey and O'Malley's (2005) steps in carrying out a scoping review by adopting the following:

1) Identify the research questions: what domain needs to be explored?

2) Find the relevant studies, through the usual means: electronic databases, reference lists (ancestor searching), websites of organizations, conference proceedings, etc.

3) Select the studies that are relevant to the question(s)

4) Chart the data, i.e., the information on and from the relevant studies

5) Collate, summarize and report the results

6) Consult stakeholders (clinicians, patients, and families, policymakers, or whatever is the appropriate group) to get more references, provide insights on what the literature fails to highlight, etc.

Option or step 6 was not done for this study. By completing the first five stages, enough and relevant information was collected. Journal articles, books, websites, etc. that considered variables, such as children and youth in care, education, achievement, and completion were extracted. The electronic databases that were used were Academic Search Complete, JSTOR, ERIC (via EBSCOhost), Google Scholar and Sage Publications. Only publications written in Journal of Contemporary Issues in Education, 2018, 13(1), pp. 3-22 
English were used. The date of publication was open, and no specific period was considered. Different types of sources were consulted including refereed publications, gray literature, handsearching and reference lists.

The reviewed studies and papers were categorized according to geographical location. As this was mainly undertaken to provide a map of the range of emerging and available evidence, and specific evidence about location (Alberta), this was not a systematic review that could have produced quantitative statistical data (Dijkers, 2015). A total of twenty-seven studies were selected for this study. Twenty were in journal articles and book chapters, four came from websites, and another two were from an examination of references. Geographically, the selected studies were broken down as; Europe (11), USA (4), and Canada (10). Studies from Canada were all from the provinces of Ontario, British Columbia, and Manitoba.

\section{Selection of Canadian Research Studies}

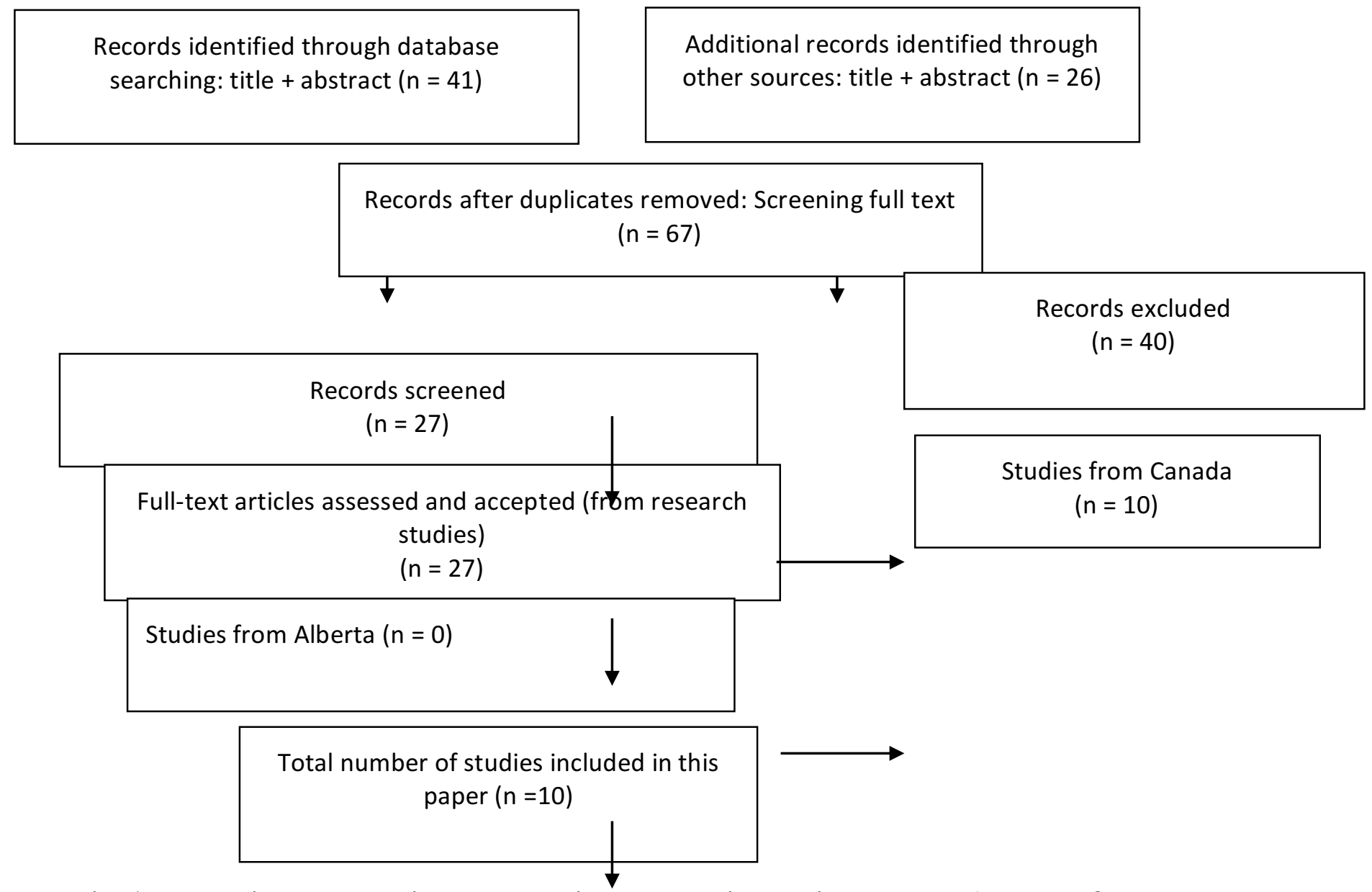

Fig. 1: The Prisma Flow Diagram showing the scoping review process (adapted from The Joanna Briggs Institute Reviewers' Manual, 2015) 


\section{Findings}

The purpose of this study was to examine the extent, range, and nature of research activity about the education of children and youth in residential care in Alberta. The scoping review wanted to show where the province of Alberta stands in comparison to other provinces in Canada and internationally. This section of the article examines studies on education of looked after children from a geographical location standpoint.

International studies on the education of children and youth in residential group care. Many studies have been carried out to inform policy and practice in the growing field of residential child and youth care. Among many issues, researchers have grappled with the problem of low achievement in education by children and youth who are looked after by local authorities (Berridge, 2012; Sugden, 2013). When one considers the importance of schooling in today's competitive market societies, the low levels of education being attained by intervention children and youth brings with it the high risk of social exclusion. Many educators had since realized that this ignored and forgotten sector of today's young population requires attention and there is a need for support and remedial attention to compensate for the earlier disruption in education when these children were not yet in care. It has been observed that social workers and child and youth care workers, mainly focus on emotional and behavioral issues and not school attainment. Research has considered children and youth in care as participants (Jackson \& Simon, 2006; Martin \& Jackson, 2012; Sugden, 2013; Höjer \& Johansson, 2013), others have considered social workers, and child and youth care workers (Brewin \& Statham, 2011; Martin \& Jackson, 2002). Some have focused on schools and teachers (Weinberg, Zeitlin \& Shea, 2009; Weinberg \& Luderer, 2004) while other studies have concentrated on reviewing developments in this area over the past decades (Coman \& Devaney, 2011; Ferguson \& Wolklow, 2012).

In the UK, the low educational achievement of looked after children was pointed out as one of the most important contemporary social problem (Berridge, 2007; Jackson, 1994; Walker, 1994). Socioeconomic risk factors such as social class, poverty, and parental maltreatment are strongly linked to educational failure. Jackson (2008) found out that even those children and youth in care who attend school regularly are unlikely to reach their educational potential unless active measures are taken to compensate for earlier disadvantages. Educational intervention has seen legislation being passed aimed at educating children in care (Badham, Frampton, Warwick \& Hudson, 2002). Low achievement and how to improve outcomes are major research areas. Brewin and Statham's (2011) study reported different factors that can enhance the educational experience of looked after children including the importance of planning and information sharing between the major stakeholders and offering holistic and individualized support. Improving outcomes is still considered a big challenge (Coman \& Devaney, 2011) and national concern (Berridge, 2013). In Scotland, Connelly and Furnivall (2013) reported that there is evidence of improvement in outcomes, notably in school attendance and the attainment of children in out of home care. All this work coming out of the UK shows the importance that is placed on the education of children and youth in care. These studies acknowledge the complexity of the process of educating looked after youth, with factors such as home background and support (residential homes and agencies policies), within-child factors, schools, and teachers, requiring to be factored in if educational outcomes are to improve. 
Studies from other countries have portrayed a picture similar to what is coming out of the UK. The challenges of poor coordination and lack of interest in education on the part of social workers was the focus of Weinberg and Luderer's (2010) and Weinberg, Zetlin and Shea's (2009) studies in the USA. In Spain Montserrat, Casas, and Malo (2013) outlined factors associated with delays in educational pathways, and these include professionals and managers in the child protection system not prioritizing education, low expectations among adults supporting them, and invisibility within the educational regime of the specific support needs of this population. If policies are to be developed to address all the above factors, it is crucial to assess what necessary changes are required to empower the potential human and social capital of this population, increase equality in their educational opportunities and reduce their high risk of social exclusion. In Sweden, the importance of the school for children and youth in care was emphasized. According to Höjer and Johansson (2013), the school can constitute a life opportunity and a resilience factor for young people at risk, as well as for those placed in care. Their study showed that school could provide a place of structure and safety, in contrast to chaotic family life. When it was impossible to bring friends home, due to parents' problems, the school also gave young people from socially and economically challenged families a chance to spend time with friends and provided them with a sense of 'normality.'

\section{Research in Canada on the education of children and youth in care}

Most of the studies that have been carried out in Canada have been in Ontario and British Columbia where institutions like the University of Ottawa, Ryerson University, University of Victoria, and the University of British Columbia have scholars and researchers who have demonstrated an interest in studying the education of children and youth in care. Studies and publications have been in line with international trends. Researchers have raised consciousness over the prevalence of educational disadvantages among children and youth in care when compared to their peers who are not looked after (Ferguson \& Wolkow, 2012; Mitic \& Rimer, 2002; Stoddart, 2012). The education of children in foster care and possible intervention to alleviate the low achievement trend was the focus of Harper and Schmidt's $(2012 ; 2016)$ as well as Flynn, Marquis, Paquet, and Peeke's (2011) studies all in Ontario. Some studies specifically address the role of child and youth care workers in enhancing the education of their clients in residential group homes (Gharabaghi, 2012). Cheung, Lwin and Jenkins (2012) examined associations between caregiver involvement and academic success in youth in care. Their study suggested that caregivers who provided more academic support at home and a more positive literacy environment were also more likely to care for youth with higher levels of academic success. Similar results and conclusions came from Flynn, Tessier and Coulombe's (2012) study, also from Ontario that observed that the caregiver's educational aspirations for the youth in care emerged as the most consistent predictor of educational success. McMillan, Stuart, and Vincent (2012) made similar observations when they observed child and youth worker interventions in learning improving educational outcomes. Kiaras Gharabaghi's (2012) work in Ontario considered whether residential/group homes supported the education and learning of youth. The need for systematic and broad change in the purpose and design of residential group care across human service providers was the main recommendation. Similar views were expressed by Stoddart (2012), Gharabaghi (2011), and Gharabaghi \& Groskleg (2010), all in Ontario. In BC, Pereira and Lavoic (2016) examined youth's perceptions of the factors that influenced their being placed in the alternate program. An extensive study was also carried out in Manitoba by Brownell et al. (2010) and it examined educational outcomes for children in care. These studies 
consider residential group care homes, children and youth in care, and to a certain extent schools or teachers. While all these stakeholders are significant, the need to include caseworkers and other child and youth care workers in understanding and promoting the education of these vulnerable children cannot be overemphasized.

There are some government publications on educating children and youth in care. In Alberta, the Provincial Protocol Framework (Alberta Education, 2010) outlines the different roles caseworkers, caregivers, teachers and children, and youth are expected to play to achieve success in school for children and youth in care. Nova Scotia has SchoolsPlus (ISD) initiative (Bennet, 2013), and a similar program exists in Saskatchewan (Saskatchewan Child Welfare Review Panel, 2010) as well as in Manitoba (Burnside, 2012). Another comprehensive national study was done by Bounajm, Beckman, and Theriault (2014) under the auspices of the Conference Board of Canada. When compared to other countries, the state of research studies on the education of children and youth in care in Canada is quite disturbing. A lot of work is being done in Ontario (Dill, Flynn, \& Hollingshead, 2012). Other provinces are lagging, and in Alberta, it appears there are no academic research projects on this topical issue that have been done to date. The table below shows what came out of this review as the only research studies on the education of children and youth in care that have been done in Canada to date.

\section{Research Studies Carried out in Canada}

\begin{tabular}{|c|c|c|c|c|}
\hline Author(s) & Province & Study Design & Population & Sample \\
\hline $\begin{array}{l}\text { 1. Harper, J., \& Schmidt, F. } \\
\text { (2016) }\end{array}$ & Ontario & $\begin{array}{l}\text { Longitudinal } 30 \text { - } \\
\text { week intervention }\end{array}$ & Foster children & 101 \\
\hline $\begin{array}{l}\text { 2. Brownell, M., Chartier, M., } \\
\text { Au, W., MacWilliam, L., } \\
\text { Schultz, J., Valdivia, W. G. J. } \\
(2015) \text {. }\end{array}$ & Manitoba & $\begin{array}{l}\text { Datasets analysis, } \\
\text { Regression } \\
\text { modeling }\end{array}$ & $\begin{array}{l}\text { Children in care (all } \\
\text { children from birth to } \\
18 \text { years who had spent } \\
\text { at least one day in care) }\end{array}$ & Unclear \\
\hline $\begin{array}{l}\text { 3. Flynn, R. J., Marquis, R., } \\
\text { Paquet, M. -P., Peeke, L.M., \& } \\
\text { Aubry, T. (2012) }\end{array}$ & Ontario & $\begin{array}{l}\text { Cross-sectional and } \\
\text { longitudinal, } \\
\text { experimental }\end{array}$ & $\begin{array}{l}\text { Young people in care in } \\
\text { Ontario }\end{array}$ & 1106 \\
\hline $\begin{array}{l}\text { 4. Mitic, W. \& Rimer, M. } \\
\text { (2002) }\end{array}$ & $\begin{array}{l}\text { British } \\
\text { Columbia }\end{array}$ & $\begin{array}{l}\text { Comparative data } \\
\text { analysis }\end{array}$ & $\begin{array}{l}\text { Students in Grades } 4,7 \\
\& 10 .\end{array}$ & Unclear \\
\hline $\begin{array}{l}\text { 5. McMillan, C.S., Stuart, C. \& } \\
\text { Vincent, J. (2012) }\end{array}$ & Ontario & $\begin{array}{l}\text { Survey/exploratory } \\
\text { qualitative research }\end{array}$ & $\begin{array}{l}\text { Alternate schooling } \\
\text { students }\end{array}$ & 7 \\
\hline $\begin{array}{l}\text { 6. Cheung, C., Lwin, K. \& } \\
\text { Jenkins, J. N. (2012) }\end{array}$ & Ontario & $\begin{array}{l}\text { Cross sectional data } \\
\text { analysis }\end{array}$ & $\begin{array}{l}\text { Youth in care in } \\
\text { Ontario }\end{array}$ & 687 \\
\hline 7. Garabhagi, K. (2012) & Ontario & $\begin{array}{l}\text { Research to practice } \\
\text { synthesis qualitative } \\
\text { synthesis }\end{array}$ & $\begin{array}{l}\text { Residential group care } \\
\text { providers }\end{array}$ & 150 \\
\hline $\begin{array}{l}\text { 8. O'Brien, M., \& Rutland, J. } \\
\text { (2008) }\end{array}$ & Ontario & $\begin{array}{l}\text { Evaluative } \\
\text { rese4arch }\end{array}$ & $\begin{array}{l}\text { Children from } 4 \text { to } 13 \\
\text { years old }\end{array}$ & 5 to 60. \\
\hline
\end{tabular}




\begin{tabular}{|l|l|l|l|l|}
\hline $\begin{array}{l}\text { 9. Harper, J., \& Schmidt, F. } \\
\text { (2012). }\end{array}$ & Ontario & Experimental design & $\begin{array}{l}\text { Foster children (Grade } \\
1-8)\end{array}$ & 68 \\
\hline $\begin{array}{l}\text { 10. Flynn, R. J. \& Biro, C. } \\
\text { (1998). }\end{array}$ & Ontario & $\begin{array}{l}\text { Case Comparisons, } \\
\text { test-retest reliability } \\
\text { and convergent } \\
\text { validity of single } \\
\text { items }\end{array}$ & Children in care & 43 \\
\hline
\end{tabular}

\section{Discussion}

\section{Research and practice on the education of children and youth in care}

This scoping review has shown that the education of children and youth in care, also referred to as looked after children or intervention children is not considered as a serious research issue in Canada judging by the scattered nature of studies in this area. A lot has been done in Europe, in countries such as the UK, Sweden, Germany and in the USA (Vacca, 2008; Zima, Bussing, Freeman, Belin, \& Forness, 2000; O'Higginsa, Sebbaa, \& Gardnerb, 2017). In Canada, the search of major electronic databases showed that almost all research studies had been done in Ontario, Manitoba and British Columbia with researchers from the University of Toronto, University of Ottawa and Ryerson University and from organizations offering children's services in Ontario heavily involved (Harper \& Schmidt, 2012; 2016; Flynn et al, 2011; 2012, Mitic and Rimer, 2002; McMillan et al, 2012; Cheung, Lwin, \& Jenkins, 2012; Gharabaghi, 2012; Forsman \& Vinnerljuna, 2012). In an era where evidence-based practice is the norm, and when the population of children and youth in care is increasing across Canada, and the conditions of those under intervention as reported by most Offices of Children's Advocate is not ideal, the lack of research in this area should worry all concerned citizens, especially caseworkers, child youth care workers, educators and the community at large as an increasing segment of society is being neglected and left behind. In Alberta, youth in care, especially the ones described as high-risk and in residential group care, spend most of the nights on the streets, abuse alcohol and other substances including hard drugs. They are not in school and caseworkers, and residential child youth care workers do not see it as their responsibility to encourage them to go to school (Ghabaraghi, 2012).

It is evident that social work approach is currently dominating child and youth care philosophies and practices while at the same time evidence is primarily showing the field of child care as multi-disciplinary. The paucity of research on the education of looked after children with nothing notable coming out of the province of Alberta confirms the observation that social workers are not educators and consequently the education/schooling of children and youth in care is not considered a priority. Trinder (1996) summed up current social practice as anti-intellectual traditions of mainstream social work ... Difficult epistemological questions and difficult substantive research questions are avoided. Research deals with the surface not depth understanding, explanation or causation (p. 238). 
Teachers find looked after children problematic and challenging (Berridge, 2012; Ghabaraghi, 2012), and unlike other students with special needs, there are no designated intervention education assistants in schools to help looked after children learn and the teachers in teaching this category of children. In spite of all these observations and international research efforts, and the dismal and alarming results that have been consistently reported (Alberta Education and Alberta Children and Youth Services, 2010), there seem to be surprisingly few examples of evaluated attempts to do something about out of home children's poor school achievements.

Against this absence of research studies on the education of children and youth in care, a gap that is disturbing in Alberta, the literature considered in this scoping review educates us on areas that require urgent attention if the rights of all children as captured in the Canadian Charter of Rights and Freedoms (1982) are to be realized. While there are policy documents that demonstrate the government of Alberta's concern on the education of children and youth in care (Provincial Policy Framework, 2010), there are no legal instruments that have been passed to specifically address this issue. Education is more than achievement as measured through grades as demanded by contemporary large-scale assessment practices (Vacca, 2008). Attendance is very important regardless of the scores. So, while low achievement has concerned most people, especially educators (Cheung, Lwin, \& Jenkins, 2012; Jackson, 1994), in the absence of schooling, as Montserrat, Casas, \& Malo (2013) observed, it is hard to prevent social exclusion of these vulnerable children. Evidence shows that the transition to adulthood has become more difficult and young people without educational qualifications are increasingly marginalized with the decline of traditional industrial and craft occupations (Vacca, 2008; Flynn \& Biro, 1998). There is, therefore, greater potential for social inequality. This is very concerning as academic success is predictive of higher levels of later well-being and success (Attar-Schwartz, 2009; Schiff \& Benbenishty, 2006; Tylor, Johnson, \& Brownridge, 2008; Cheung, Lwin, \& Jenkins, 2012). It is well established that a preoccupation with school, education, and learning not only improves formal education outcomes but in fact also improves general life competencies and mental health functioning. This means child and youth care oriented towards a philosophy of education replaces psychotherapeutic approaches with education and learning-focused approaches as the core of worker-client interaction and residential home management (Ghabaraghi, 2011).

Even though the Government of Alberta, through Alberta Education and Alberta Children's Services has recognized the problem for decades, little has been done to build empirically supported interventions. Interventions aiming at enhancing children and youth in care's school achievements seem to have a good chance of producing positive results. Forsman and Vinnerljung (2012) observed that replications of, for example, the Ontario tutoring programs (see Flynn et al., 2012; Harper \& Schmidt, 2016) could be staged in new locations with optimistic expectations. This means such tutoring interventions can be done here in Alberta to improve the educational experiences of children and youth in care. For the research community, this means there is the need for far more intervention studies, especially replications with large samples and experimental design of promising interventions.

\section{Social workers, carers and the education of looked after children and youth}

Social workers in their different roles in child and youth care are supposed to play an important role in the education of children and youth in care. Some caseworkers have parental guardianship authority for looked after children (Government of Alberta, 2000) while residential care workers Journal of Contemporary Issues in Education, 2018, 13(1), pp. 3-22 
occupy an in loco parentis position as they supplant birth parents (Berridge, 2012). This special relationship calls for government, guardians, and child-serving agencies to be a kind, judiciousand caring-parent (Representative for Children and Youth and the British Columbia Office of the Provincial Health Office, 2009). Research has established that higher academic achievement has been found to be associated with higher parental expectations concerning school. This has been consistently demonstrated across cross-sectional (Davis- Kean, 2005) and longitudinal studies (Dotterer, McHale, \& Crouter, 2009; Rutchick, Smyth, Lopoo, \& Dusek, 2009). Moreover, relative to other dimensions of parental involvement, parental expectations appear to have the strongest effect on academic achievement. This, therefore, calls for an educational role for caseworkers and child and youth care workers. As already captured above, current child welfare practice tends to be rather narrow and that this inhibits the analysis of complex social problems, including the low educational attainment of children in care (Berridge, 2007). Some research has concluded that delays in education improvement or performance by children and youth in care were related to professionals and managers in the child protection systems not prioritizing education. Where care givers are supportive of children's education, evidence of improvement in outcomes, notably in school attendance have been noted (Connely \& Furnival, 2013; Montserrat, Casas, \& Malo, 2013).

One of the strongest influences on educational attainment remains social class (Gunn, 2005; Wilder, 2014), often analyzed by parental occupation (non-manual and manual occupations). Social class is linked to cognitive development for preschool children, as well as achievements on entry and during junior school. Most children and youth in care come from socially and economically challenged homes that were abusive and mostly poor or lower class (Ghabaraghi, 2011). The question is what class do residential group homes occupy in Alberta/Canada? When one considers the culture in residential group homes as defined by the influence of agency policies and recruitment criteria, children and youth in care have not changed class - it is still the low class associated with antisocial behavior like smoking, drug abuse, unprotected sex and early pregnancies among many other unwanted traits. Sociology of education has taught us that teachers' assessments of pupils' abilities have been found to be associated with social class independent of ability, with teachers having more favorable views of children from non-manual backgrounds. The negative attitude of teachers towards children and youth in care is well documented. Overall, therefore, although the school can make a difference to pupils' achievements, West and Pennel (2003) cite Gorard's (2000) conclusion that “...the inequalities in society outweigh the differences between schools" (p. 571). Looked-after children emanate from the poorest social groups, and parental involvement and support have often been problematic, and all this has a significant influence on achievement.

Tideman, Vinnerljung, \& Hintze (2011) observed that it is common for the child and youth care workers, social workers and teachers to have pessimistic expectations on children and youth in care's school performance. In contrast, it is well established that middle-class families use a variety of economic, cultural and social strategies to ensure that their children do well at school, including paying for private education (Devine, 2004). They can also create the opportunity to repeat examinations. Also, cultural capital (Bourdieu, 1973) is used to their social advantage, reflected in language use and attitudes towards education, instilling appropriate values of "hard work, discipline and deferred gratification" (Devine 2004, p. 180). It is against these observations that Berridge (2007) concluded that if society genuinely wants children and youth Journal of Contemporary Issues in Education, 2018, 13(1), pp. 3-22 
in care to do well at school, the government needs to match some of these common middle-class strategies. The parental involvement that is common among middle-class families includes parental involvement with school-related activities, providing a positive home literacy environment (e.g., access to books, visits to the library), and expectations they hold towards the value and utility of education. Extending Berridge's view would mean that residential homes where looked after children are living should have these features. School-based involvement would refer to social workers and child and youth care workers' interactions with schools and teachers that promote academic success for children and youth in care.

\section{Youth placement and education}

Studies have illuminated the importance of where children and youth live. The importance of permanency for children and youth receiving Government of Alberta intervention services is emphasized in most government documents and policies (See Government of Alberta's Child, Youth and Family Enhancement Act, 2000). Relative to those in foster care, children, and youth placed in group care are more likely to demonstrate worse academic outcomes (Berrick, Barth, \& Needell, 1994; Stone, 2007). Youth living in residential therapeutic group homes have been found to be three times more likely to repeat at least one grade when compared to those in kinship placements (Zima et al., 2000). Also, youth from placements that are more short-term have higher levels of peer violence. These short-term placements offered fewer after-school activities and are more likely to care for youth with lower levels of achievement (Cheung, Lwin, \& Jenkins, 2012, p. 1093). These studies should be informing the education of children and youth in care in Alberta. Without implementing these policies and putting in place necessary educational supports, we do not know the educational capabilities of children and youth in care.

Child and youth care agencies move clients from one program to another, in most cases for management and behavior control considerations. The children and youth's education is affected negatively, not only because of consistent changes in the child's home environment but sometimes changes in group homes mean changing schools. Teachers complain that they are not informed by agencies when children are moved (Ghabaraghi, 2011). Placement issues are further complicated by high turnover rates of staff within residential care. According to Gharabaghi (2010), the demands of care work can prove daunting for many child and youth care workers who often choose to seek employment elsewhere. The constant change of staff disrupts the living and learning conditions of looked after children. They end up losing consistent support as different workers have different expectations and abilities. Coupled with the absence of an educational thrust in most agencies and residential care homes (Ghabaraghi, 2011), the chance of getting a supportive corporate parent is close to zero.

\section{Child-related explanations}

The studies that were reviewed further alerted to the fact that children and youth experiencing difficulties at school may well be having problems at home as well. According to Mills (2004), "much of the poor school performance of looked after children may be explained by histories of maltreatment" (p. 4). A study cited by Berridge (2007), discovered that the educational performance of pupils admitted to care because of neglect or abuse was lower than that of pupils separated for other reasons. Most interventions are due to abuse and neglect that children would be facing. This is important to put into consideration if Alberta's programs such as Success in School are to be successful. 
Other research studies have reported that children and youth that have spent at least a third of their formative years in care have very high excess risks, compared to their general population peers, for example, suicidal behavior, severe criminality, and substance abuse (Berlin, Vinnerljung, \& Hjern, 2011). The existence of these kinds of actions negatively impacts the children's education. According to Cheung, Lwin, and Jenkins (2012), youth in care with better impulse inhibition, and emotion regulation, and higher language ability are more likely to show higher levels of academic success. It has also been discovered that particular types of abuse are associated with low educational achievement of children and youth in care. Relative to those classified as neglected alone or sexually abused alone, youth with the experience of physical abuse are more likely to experience school-related suspensions or discipline (Cheung, Lwin, \& Jenkins, 2012; Eckenrode, Laird, \& Doris, 1993). However, for children with a history of neglect alone, they appear to be at a heightened risk for general deficits across multiple domains of academic success (Eckenrode, Laird, \& Doris, 1993; Kendall-Tackett \& Eckenrode, 1996).

\section{School accommodation and environment}

Research consistently shows the invisibility within the educational system of the particular support needs of children and youth in care (Montserrat, Casas, \& Malo, 2013). There are no assistant teachers in classrooms to help children and youth in care. Many other vulnerable groups are accommodated under special education provisions, but this is not the case with out of home children despite overwhelming evidence that they are low achievers. School attendance for children in care is abysmal. While some studies have shouldered the blame on residential homes where the children live and others to inadequacies in social work (Ghabaraghi, 2012), schools must do shoulder some blame. Some other studies have concluded that inadequate information was held by local educational authorities about looked-after children's educational careers and that insufficient effort was being made to address pupils' negative attitudes towards schooling (Berridge, 2007, p. 3). Schools are accused of quickly suspending students who come from care homes.

This review also discovered that children and youth in foster care do better than those living in group homes (Flynn et al. 2012) and it is believed teachers tend to have positive attitudes towards children in foster care. Other scholars have claimed that foster children's school achievements are as bad/good as can be expected, considering the children's adverse early childhood experiences. However, Berlin, Vinnerljung and Hjern (2011) and Vinnerljung and Hjern (2011) argued that children and youth from care are not damaged goods. If provided with adequate support, they seem to be able to improve in school.

\section{Conclusion and Recommendations}

Residential group care must be designed to support education, both regarding formal school experiences and performance as well as informal learning, in all aspects of the day-to-day operation. From policies and procedures to hiring criteria and professional development activities for staff, and from the types of food served to the nature of programming activities, residential group care must engender experiences for young people that provide encouragement and support for higher performance at

Journal of Contemporary Issues in Education, 2018, 13(1), pp. 3-22 
school as well as expectations that every young person can achieve

academic success. (Gharabhaghi, 2011, p. 87)

The above points to the inadequacies of the home environment where children and youth in care live. However, this review found out the entire children and youth services approach to be inadequate and failing the education of children and youth in care. Looked after children and youth come from some of the most disadvantaged social groups, characterized by family breakdown, parental poverty, and maltreatment among many other issues meaning they have "high level of special educational need - all of which are strongly linked to low educational attainment...." (Berridge, 2007, p. 8). This may mean being looked after constitutes an educational risk factor. However, there are no studies that have demonstrated that being looked after leads to low school achievement-showing the extent this field is undertheorized.

The aim of interventions in abused children is to allow educational, and care services compensate the social disadvantages the children had encountered before the intervention. With continued low achievement in education being reported, the whole intervention process is questioned. This review found this to be a complex issue because the factors that cluster to predict entry to care are also associated with educational failure. Nacro (2012) observed that it is inadequate to argue that the care system does not worsen attainment; it should compensate for the previous social disadvantage and significantly reduce it. Many scholars question the care system's ability to enhance the life of children and youth genuinely. These many unanswered questions are not surprising considering the lack of research in this area. This review showed that very few studies had been carried out in Canada, almost all of them in Ontario. As this paper wanted to highlight the situation in the province of Alberta, it is clear not much has been done. There is need to replicate and improve on some of the studies that have been done elsewhere. The education of children and youth in care is essential if the current challenges to drug abuse and other illegal and anti-social activities are to be tackled. Studies have shown that children and youth in care who attend and complete education are aware of the dangers of drug use and can abstain from dealing in drugs (see Henderson, Hawke, \& Chaim 2017). Other benefits of education that include enabling one to participate in economic activities of society need not be regurgitated here. Consequently, this review recommends the following:

- There is the need for research in Alberta to encourage evidence-based practice in Alberta Children's Services and Alberta Education ministries.

- There is need to place education at the center of government of Alberta's intervention policies and practices. Currently, as seen from other provinces and internationally, child care is mainly practiced from a social work perspective that emphasizes safety and control and not individual development of the child.

- Various agencies and individuals in charge of the educational needs of children in care must cooperate and coordinate their activities. This need applies most to school and child welfare agencies.

- Attention must be given to more comprehensive training for all those in charge of children and youth, greater stability of children's educational placements, increased education supports for youth, and more extensive educational planning and monitoring. (Ferguson \& Wolkow, 2012) 
- Child welfare agencies should consider hiring educators to act as bridges to the education system. These "transplanted" educators provide advice to staff on how to access resources within the school system, and broker placements and resource acquisition.

- There is urgent need to consider the introduction of support workers/assistants in schools that are responsible for children and youth from care facilities in the same manner children with special needs are accommodated.

- Children and youth in care are a special need category.

\section{References}

Alberta Education. (2009). Your key to success: administrator's guide for raising Alberta's high school completion rate. Edmonton: Crown in Right of Alberta.

Alberta Education and Alberta Children and Youth Services. (2010). Success in school for children and youth in care: provincial protocol framework. Edmonton: Government of Alberta: Available at https://open.alberta.ca/dataset/71620935-fa49-401e-ac04b740f186826e/resource/2c8c2851-9751-438f-9a08-8579fcaeb345/download/50789442010-Success-in-School-for-Children-and-Youth-in-Care-2010-11.pdf.

Arksey, H., \& O’Malley, L. (2005). Scoping studies: Towards a methodological framework. International Journal of Social Research Methodology: Theory \& Practice, 8(1), 19-32. https://doi.org/10.1080/1364557032000119616

Attar-Schwartz, S. (2009). School functioning of children in residential care: the contribution of multilevel correlates. Child Abuse and Neglect, 33, 429-440. https://doi.org/10.1016/j.chiabu.2008.12.010

Badhan, B., Frampton, P., Hudson, B., \& Warwick, K. (2002). Behind the headlines: Child safeguarding children, education and training. Hampshire: Hampshire County Council.

Bennet, P. W. (2013). Reclaiming at-risk children and youth: A review of Nova Scotia's SchoolsPlus (ISD) initiative. Halifax, Nova Scotia: Atlantic Institute for Market Studies.

Berlin, M., Vinnerljung, B., \& Hjern, A. (2011). School performance in primary school and psychosocial problems in young adulthood among care leavers from long term foster care. Children and Youth Services Review, 33, 2489-2497. http://doi:10.1016/j.childyouth.2011.08.024.

Berrick, J. D., Barth, R. P., \& Needell, B. (1994). A comparison of kinship foster homes and foster family homes: Implications for kinship foster care as family preservation. Children and Youth Services Review, 16(1-2), 33-63. http://dx.doi.org/10.1016/0190-7409(94)90015-9.

Berridge, D. (2007). Theory and explanation in child welfare. Child and Family Social Work, 12, 1-10. https://doi.org/10.1111/j.1365-2206.2006.00446.x

Berridge, D. (2012). Educating young people in care: What have we learned? Children and Youth Services Review, 34, 1171-1175. https://doi.org/10.1016/j.childyouth.2012.01.032

Berridge, D. (2013). Policy transfer, social pedagogy and children's residential care in England. Child and Family Social Work, 76-84. https://doi.org/10.1111/cfs.12112

Bounajm, F., Beckman, K., \& Theriault, L. (2014). Success for all: The economic case for investing in the future of Canadian children in care. The Conference Board of Canada.

Journal of Contemporary Issues in Education, 2018, 13(1), pp. 3-22 
Available at https://www.conferenceboard.ca/(X(1)S(bbhkcrxwaacm1zfpstztxfz3))/eLibrary/abstract.aspx?did=5949

Bourdieu, P. (1973). Cultural reproduction and social reproduction. In R. Brown (Ed.), Knowledge, education and social change: Papers in the sociology of education (pp. 71112). Tavisock, UK: Tavistock Publications.

Brewin, M., \& Statham, J. (2011). Supporting the transition from primary school to secondary school for children who are looked after. Educational Psychology in Practice, 27(4), 365381. http://dx.doi.org/10.1080/02667363.2011.624301

Brownell, M. D., Roos, N. P., MacWilliam, L., Leclair, L., Ekuma, O., \& Fransoo, R. (2010). Academic and social outcomes for high-risk youths in Manitoba. Canadian Journal of Education, 33(4): 804-836.

Burnside, L. (2012). Youth in care with complex needs: Special report for the Office of the Children's Advocate. Winnipeg, Man: Manitoba Office of the Children's Advocate. Available at http://www.childrensadvocate.mb.ca/wp-content/uploads/Youth-withComplex-Needs-Report-final.pdf

Cheung, S. Y., \& Heath, A. (1994). After Care: The education and occupation of adults who have been in care. Oxford Review of Education, 20(3), 361-374.

Cheung, C., Lwin, K., \& Jenkins, J. M. (2012). Helping youth in care succeed: Influence of caregiver involvement on academic achievement. Children and Youth Services Review, 34(6), 1092-1100. https://doi.org/10.1016/j.childyouth.2012.01.033

Child Intervention Division (2017). Child Intervention Information and Statistics Summary 2016/17 Fourth Quarter (March) Update, p. 2). Available at http://www.humanservices.alberta.ca/documents/child-intervention-info-stats-summary2016-17-q3.pdf.

Chiefs Assembly on Education. (2012). Federal funding for First Nations schools. Available at http://www.afn.ca/uploads/files/events/fact_sheet-ccoe-3.pdf

Colquhoun H.L., Levac, D., O’Brien, K. K., Straus, S., Tricco, A. C., Perrier, L., Kastner, M., \& Moher, D. (2014). Scoping reviews: time for clarity in definition, methods, and reporting. Journal of Clinical Epidemiology, 67(12), 1291-1294. http://doi:10.1016/j.jclinepi.2014.03.013

Coman, W., \& Devaney, J. (2011). Reflecting on outcomes for looked-after children: An ecological perspective. Child Care in Practice, 17(1), 37-53. http://dx.doi.org/10.1080/13575279.2010.522976

Connelly, G., \& Furnivall, J. (2013). Addressing low attainment of children in public care: The Scottish experience. European Journal of Social Work, 16(1), 88-104. http://dx.doi.org/10.1080/13691457.2012.722986

Davis-Kean, P. (2005). The influence of parent education and family income on child achievement: The indirect role of parental expectations and the home environment. Journal of Family Psychology, 19, 294-304.

Devine, F. (2004). Class practices: How parents help their children get good jobs. Cambridge: Cambridge University Press.

Dijkers, M. (2015). What is a scoping review? KT Update, 4(1), 1-4.

Dill, K., Flynn, R. J., Hollingshead, M. \& Fernandez, A. (2012). Editorial: Improving the educational achievement of young people in out-of-home care. Children and Youth Services Review, 34, 1081-1083. https://doi.org/10.1016/j.childyouth.2012.01.031 
Dotterer, A., McHale, S., \& Crouter, A. (2009). The development and correlates of academic interests from childhood through adolescence. Journal of Educational Psychology, 101, 509-519. http://dx.doi.org/10.1037/a0013987.

Eckenrode, J., Laird, M., \& Doris, J. (1993). School performance and disciplinary problems among abused and neglected children. Developmental Psychology, 29, 53-62.

Ferguson, H. B., \& Wolkow, K. (2012). Educating children and youth in care: A review of barriers to school progress and strategies for change. Children and Youth Services Review, 34(6), 1143-1149. https://doi.org/10.1016/j.childyouth.2012.01.034

Flynn, R. J., \& Biro, C. (1998). Comparing developmental outcomes for children in care with those for other children in Canada. Children and Society, 12(3), 228-233. https;10.1111/j.1099-0860.1998.tb00070.x.

Flynn, R. J., Tessier, N. G., \& Coulombe, D. (2012). Placement, protective and risk factors in the educational success of young people in care: Cross-sectional and longitudinal analyses. European Journal of Social Work, 16(1), 70-87. http://dx.doi.org/10.1080/13691457.2012.722985

Flynn, R. J., Marquis, R. A., Paquet, M. P., \& Peeke, L. M. (2011). Effects of tutoring by foster parents on foster children's academic skills in reading and math: A randomized effectiveness trial: Final report of the RESPS Kids In Care Project. Ottawa: Canada's University. Available at https://www.maloneymethod.com/wpcontent/uploads/2012/07/ef_tu_foster_parents.pdf

Flynn, R. J., Marquis, R. A., Paquet, M. P., Peeke, L. M., \& Aubry, T. D. (2012). Effects of individual direct-instruction tutoring on foster children's academic skills: A randomized trial. Children and Youth Services Review, 34, 1183-1189. http://dx.doi.org/10.1016/j.childyouth.2012.01.036.

Forsman, H., \& Vinnerljung, B. (2012). Interventions aiming to improve school achievements of children in out of home care. Children and Youth Services Review, 34, 1084-1091. https://doi.org/10.1016/j.childyouth.2012.01.037

Gharabaghi, K. (2010). In-service training and professional development in residential child and youth care settings: A three sector comparison in Ontario. Residential Treatment for Children and Youth, 27(2), 92-114. https://doi.org/10.1080/08865711003712550

Gharabaghi, K. (2011). A culture of education: Enhancing school performance of youth living in residential group care in Ontario. Child Welfare, 90(1), 75-91.

Gharabaghi, K. (2012). Translating evidence into practice: Supporting the school performance of young people living in residential group care in Ontario. Children \& Youth Services Review, 34, 1130-1134. https://doi.org/10.1016/j.childyouth.2012.01.038

Gharabaghi, K. \& Groskleg, R. (2010). A social pedagogy approach to residential care: Balancing education and placement in the development of an innovative child welfare residential program in Ontario, Canada. Child Welfare, 89(2), 97-114.

Gilligan, R. (2007). Adversity, resilience and the educational progress of young people in public care. Emotional and Behavioral Difficulties, 12(2), 135-145.

http://dx.doi.org/10.1080/13632750701315631

Government of Alberta (2010). Success in school for children and youth in care: Provincial Protocol Framework. Edmonton, Alberta Queen's Printer.

Government of Alberta. (2000). Child, Youth and Family Enhancement Act. Edmonton: Alberta Queen's Printer.

Journal of Contemporary Issues in Education, 2018, 13(1), pp. 3-22 
Gunn, S. (2005). Translating Bourdieu: cultural capital and the English middle class in historical perspective. The British Journal of Sociology, 56(1), 49-64. https://doi:10.1111/j.1468-4446.2005.00046.x

Gunn, T. M., Chorney, D. W., \& Poulsen, J. C. (2008). High school completion: AISI Provincial Research Review. Edmonton: Alberta Education and University of Lethbridge.

Harper, J., \& Schmidt, F. (2012). Preliminary effects of a group-based tutoring program for children in long-term foster care. Children and Youth Services Review, 34, 1176-1182. http://dx.doi.org/10.1016/j.childyouth.2012.01.040.

Harper, J., \& Schmidt, F. (2016). Effectiveness of a group based tutoring program for children in foster care: A randomized controlled trial. Children and Youth Services Review, 67, 238-246. https://doi.org/10.1016/j.childyouth.2016.06.009

Henderson, J. L., Hawke, L. D., \& Chaim, G. (2017). Not in employment, education or training: Mental health, substance use, and disengagement in a multi-sectoral sample of serviceseeking Canadian youth. Children and Youth Services Review, 75, 138-145. https://doi.org/10.1016/j.childyouth.2017.02.024

Höjer, I., \& Johansson, H. (2012). School as an opportunity and resilience factor for young people placed in care. European Journal of Social Work, 16(1), 1-5. https://doi.org/10.1080/13691457.2012.722984

Humphreys, A. (2014, January 24). 'A lost tribe': Child welfare system accused of repeating residential school history. The National Post. Retrieved from http://nationalpost.com/news/canada/a-lost-tribe-child-welfare-system-accused-ofrepeating-residential-school-history-sapping-aboriginal-kids-from-their-homes

Jackson, S. (1994). Educating children in residential and foster care. Oxford Review of Education, 20(3), 267-279. https://doi.org/10.1080/0305498940200301

Jackson, S. (2008). Educational success for looked-after children: The social worker's responsibility. Social Work in Action, 10(4), 47-56. http://dx.doi.org/10.1080/09503159808411503

Jackson, S., \& Simon, A. (2006). The costs and benefits of educating children in care. In E. Chase, A. Simon, \& S. Jackson (Eds.), In care and after: a positive perspective (pp. 4462). London and New York: Routledge.

Kendall-Tackett, K. A., \& Eckenrode, J. (1996). The effects of neglect on academic achievement and disciplinary problems: A developmental perspective. Child Abuse \& Neglect, 20(3), 161-169. http://dx.doi.org/10.1016/S0145-2134(95)00139-5.

Leiter, J., \& Johnsen, M. C. (1997). Child maltreatment and school performance declines: An event-history analysis. American Educational Research Journal, 34, 563-589. https://doi.org/10.3102/00028312034003563

Martin, P. Y., \& Jackson, S. (2002). Educational success for children in public care: Advice from a group of high achievers. Child and Family Social Work, 7, 121-130. https://doi.org/10.1046/j.1365-2206.2002.00240.x

Mills, C. (2004). Problems at home, problems at school. London: National Society for the Prevention of Cruelty to Children.

Mitic, W., \& Rimer, M. (2002). The educational attainment of children in care in British Columbia. Child and Youth Care Forum, 31(6), 397-414. https://doi:10.1023/A:1021158300281. 
McMillan, C., Stuart, C., \& Vincent, J. (2012). Tell it like you see it: Youth perceptions of child and youth care practitioner interventions and outcomes in an alternative school setting. International Journal of Child, Youth and Family Studies, 2 \& 3, 214-233.

Montserrat, C., Casas, F., \& Malo, S. (2013). Delayed educational pathways and risk of social exclusion: The case of young people from public care in Spain. European Journal of Social Work, 16(1), 6-21. http://dx.doi.org/10.1080/13691457.2012.722981

Morin, B. (2017, August 31). First Nations students face continued funding shortfalls, advocate says. $C B C$ News. Retrieved from http://www.cbc.ca/news/indigenous/first-nationsstudents-face- continued-funding-shortfalls- 1.4267540

Nacro (2012). Reducing offending by looked after children. London: Nacro.

O'Brien, M., \& Rutland, J. (2008). Outcomes of a supplemental learning program for children in care at family and children's services of Renfrew County. Oacas Journal, 52(4), 11-14. Retrieved from http://www.oacas.org/pubs/oacas/journal/2008Fall/program.html

O’Higginsa, A., Sebbaa, J., \& Gardnerb, F. (2017). What are the factors associated with educational achievement for children in kinship or foster care: A systematic review. Children and Youth Services Review, 79, 198-220. https://doi.org/10.1016/j.childyouth.2017.06.004

Pereira, L. C., \& Lavoic, J. (2016). Students' perceptions of schooling: The path to alternate education. International Journal of Child, Youth and Family Studies, 7(3/4), 381-403. http://dx.doi.org/10.18357/ijcyfs73-4201616091

Phillips, R. (2011). The absentee Minister of Education of Canada: The Canadian Federal Government's constitutional role in First Nations education. McGill Journal of Education. 46(2), 231-245. https://10.7202/1006437ar

Reid, C. (2007). The transition from state care to adulthood: International examples of best practices. New Directions for Youth Development, 113, 33-49.

Representative for Children and Youth and the British Columbia Office of the Provincial Health Office [Joint Report]. (2009). Health and wellbeing of children in care in British Columbia: Educational Experience and Outcomes. Victoria. Available at https://rcybc.ca/sites/default/files/documents/pdf/reports_publications/health_and_wellbe ing_of_cic.pdf

Rutchick, A. M., Smyth, J. M., Lopoo, L. M., \& Dusek, J. B. (2009). Great expectations: The biasing effects of reported child behavior problems on educational expectancies and subsequent academic achievement. Journal of Social and Clinical Psychology, 28, 392413. https://doi.org/10.1521/jscp.2009.28.3.392

Saskatchewan Child Welfare Review Panel. (2010). For the good of our children and youth: A new vision, a new direction: Saskatchewan Child Welfare Review Panel report. Regina, Sask: Saskatchewan Child Welfare Review Panel.

Schiff, M., \& Benbenishty, R. (2006). Functioning if Israeli group homes alumni: Exploring the differences and in care correlates. Children and Youth Services Review, 28, 133-157. https://doi.org/10.1016/j.childyouth.2005.02.010

Sherlock, T. (2017, November 22). Disproportionate number of Aboriginal children in foster care. Vancouver Courier. Available at http://www.vancourier.com/opinion/disproportionate-number-of-aboriginal-children-infoster-care-1.23101923.

Journal of Contemporary Issues in Education, 2018, 13(1), pp. 3-22 
Snow, K. (2009). The case for enhanced educational supports for children in public care: An integrative literature review of the educational pathway of children in care. Vulnerable

Children and Youth Studies, 4(4), 300-311. https://doi.org/10.1080/17450120903012933

Stoddart, J. K. (2012). Using research and outcome data to improve educational services and supports for young people in care: A case study of a local children's aid society in Ontario. Children and Youth Services Review, 34(6), 1154-1160.

https://doi.org/10.1016/j.childyouth.2012.01.045

Stone, S. (2007). Child maltreatment, out-of-home placement, and academic vulnerability: A fifteen-year review of evidence and future directions. Children and Youth Services Review, 29(2), 139-161. http://dx.doi.org/10.1016/j.childyouth.2006.05.001

Sugden, E. J. (2013). Looked-after children: what supports them to learn? Educational Psychology in Practice, 29(4), 367-382. http://dx.doi.org/10.1080/02667363.2013.846849

The Joanna Briggs Institute. (2015). The Joanna Briggs Institute reviewers' manual 2015: Methodology for JBI scoping reviews. Adelaide, Australia: The Joanna Briggs Institute.

Tideman, E., Vinnerljung, B., \& Hintze, K. (2011). Improving foster children's school achievement. Promising results from a Swedish intensive study. Adoption and Fostering, 35(1), 44-56. https://doi.org/10.1177/030857591103500106

Trinder, L. (1996) Social work research: the state of the art (or science). Child and Family Social Work, 1, 233-242.

Tylor, K., Johnson, K., \& Brownridge, D. (2008). A longitudinal study of the effects of child maltreatment on later outcomes among high-risk adolescents. Journal of Youth and Adolescence, 37, 506-521. https://doi.org/10.1007/s10964-007-9250-y

Vacca, J. S. (2008). Crime can be prevented if schools teach juvenile offenders to read. Children and Youth Services Review, 30, 1055-1062. https://doi.org/10.1016/j.childyouth.2008.01.013

Vinnerljung, B., \& Hjern, A. (2011). Cognitive, educational and self-support outcomes of longterm foster care versus adoption. A Swedish national cohort study. Children and Youth Services Review, 33(10), 1902-1910. http://dx.doi.org/10.1016/j.childyouth.2011.05.016.

Walker, T. G. (1994). Educating children in the public care: A strategic approach. Oxford Review of Education, 20(3), 339-347.

Weinberg, L., \& Luderer, J. W. (2010). Problems and solutions to improving education services for children in foster care. preventing school failure. Alternative Education for Children and Youth, 48(2), 1-7. https://doi.org/10.3200/PSFL.48.2.31-36

Weinberg, L. A; Zetlin, A., \& Shea, N. M. (2009). Removing barriers to educating children in foster care through interagency collaboration: A seven-county multiple-case study. Child Welfare, 88(4), 77-111.

West, A., \& Pennel, H. (2003). Underachievement in schools (school concerns). London: Routledge

Wilder, S. (2014). Effects of parental involvement on academic achievement: A meta-synthesis. Education Review, 66(3), 377-397. http://dx.doi.org/10.1080/00131911.2013.780009.

Zima, B. T., Bussing, R., Freeman, S., Belin, T., \& Forness, S. R. (2000). Behavior problems, academic skill delays and school failure among school-aged children in foster care: Their relationship to placement characteristics. Journal of Child and Family Studies, 9(1), 87-103. https://doi:10.1023/A:1009415800475

Journal of Contemporary Issues in Education, 2018, 13(1), pp. 3-22 